\title{
Spiritualitas, Doa Dan Prestasi Belajar
}

\author{
Rio Pebrian, Nurul Istiqomah, Susi Mutoharoh \\ Universitas Ahmad Dahlan (UAD) Yogyakarta \\ Riopebrian4567899@gmail.com, Twinstiqomah1110@gmail.com, \\ Susimutoharoh35@gmail.com
}

\begin{abstract}
The purpose of this study is to examine aspects of prayer spirituality in the perspective of neuroscience and its implications for achievement. To see the relationship between the attitude of spirituality that is usually associated with prayer and endeavor, including business with the results obtained when done doing so. There is no connection between the brain and the activities of the owner of the brain because it is in the head and human activities are usually carried out in the outside area, but if you have studied the brain, especially neuroscience learning, then the body parts and what the owner does are interconnected. The results of the analysis mostly suggest that spirituality and learning achievement have relationships. The results of the study show that spirituality can be a predictor in one's learning achievement.
\end{abstract}

Keywords: Research Analysis; Spirituality; and Learning

Abstrak: Tujuan penelitian ini adalah mengkaji aspek spiritualitas doa dalam perspektif neurosains dan implikasinya terhadap prestasi. Untuk melihat hubungan antara sikap spiritualitas yang biasa berhubungan dengan doa dan ikhtiar termasuk usaha dengan hasil yang didapatkan ketika selesai melakukan hal tersebut. Tidak ada hubungan antara otak dan kegiatan pemilik otak karena ada didalam kepala dan kegiatan manusia biasa dilakukan di area luar, tetapi jika sudah mendalami pembelajaran tentang otak terutama pembelajaran neurosains, maka antara bagian tubuh dan apa yang dilakukan oleh pemiliknya itu saling berhubungan. Hasil dari analisis kebanyakan mengarahkan bahwa spiritualitas dan prestasi belajar mempunyai hubungan. Hasil penelitian menunjukkan bahwa spiritualitas dapat menjadi sebagai prediktor dalam seseorang meraih prestasi belajar.

Kata kunci: Analisis Penelitian; Ppiritualitas; dan Prestasi Belaja 


\section{Pendahuluan}

Menurut Boadella, religiusitas berasal dari kata Latin yaitu religere, yang berarti berhubungan kembali dengan sumber yang lebih dalam. ${ }^{1}$ Sementara Gazalba berpendapat bahwa Religiusitas berasal dari kata religi bahasa latin"religio" yang akar katanya adalah religure yang berarti mengikat. Pengertian ini mengandung makna bahwa religi atau agama pada umumnya memiliki aturanaturan dan kewajiban-kewajiban yang harus dipatuhi dan dilaksanakan oleh pemeluknya. ${ }^{2}$ Semua itu berfungsi untuk mengikat seseorang atau sekelompok orang dalam hubungan dengan Tuhan, sesama manusia dan alam sekitarnya. Tradisional spiritualitas berkaitan erat atau identik dengan konsep religiusitas. Namun, selama bertahun-tahun, meskipun telah banyak usaha yang telah dilakukan, masih sedikit kesepakatan yang dicapai mengenai kedua istilah tersebut. ${ }^{3}$ Spiritualitas dan agama memiliki hubungan dengan aspek kognitif, emosional, perilaku, interpersonal dan psikologis yang membentuk sebagai pendekatan holistik untuk memahami individu. Banyak penelitian telah membahas agama dan spiritualitas yang mempengaruhi dalam kehidupan manusia.

Berbagai definisi dari dua konsep telah diusulkan oleh para ahli yang berbeda dengan berbagai pandangan mulai dari polarisasi dari dua konsep tersebut, keterkaitan antara spiritualitas dan agama, sampai ada pula beberapa ulama yang menyarankan salah satunya menjadi subdomain dari yang lain, sementara ulama lain menyarankan berlawanan. Reich menyebutkan empat cara yang bisa dilakukan untuk menggambarkan hubungan antara religiusitas dan spiritualitas, yaitu ${ }^{4}$ : bahwa keduanya adalah domain yang terpisah, bahwa keduanya adalah domain yang berbeda tetapi tumpang tindih, bahwa keduanya adalah sama, dan bahwa salah satu adalah subdomain bagi yang lain. Kelly mengemukakan bahwa spiritualitas merupakan pengalaman subjektif seseorang dari transendental sifat alam semesta sementara agama dianggap ekspresi institusional dalam menampilkan spiritualitas. ${ }^{5}$

\footnotetext{
${ }^{1}$ Pasiak T. Manajemen Kecerdasan: Memberdayakan IQ/EQ/SQ untuk Kesuksesan Hidup. Bandung: Mizan, 2006: 12

2 Pasiak T. Neuron to Nation. Dewan Riset Nasional-BPPT. Disampaikan di Jakarta, Agustus 2012: 57

${ }^{3}$ Bastaman, Hana Djumhana, Integrasi Psikologi Dengan Islam; Menuju Psikologi Islam, Yogyakarta: Pustaka Pelajar, 1997: 549)

${ }^{4}$ Hamid AY. Bunga Rampai Asuban Keperawatan. Jakarta: Penerbit Buku Kedokteran EGC, 2008: 149

${ }^{\cdot 5}$ Kelly , 1995: 227
} 
Spiritualitas adalah pengalaman universal, kurang dibatasi oleh doktrin terkait dengan agama tertentu Mengingat definisi spiritualitas dan agama yang disebutkan di atas bervariasi, maka kiranya bijaksana untuk mempertimbangkan pendapat Singleton et al dalam menawarkan definisi spiritualitas dengan kesadaran tujuan hidup berdasarkan rujukan transenden. ${ }^{6}$ Bahwa definisi spiritual tidak leksikal. Ini berarti bahwa Singleton tidak membuat klaim bahwa definisi spiritualitasnya adalah ringkasan dari bagaimana orang lain menggunakan konsep tersebut. Pendapat lain juga tidak bertujuan untuk membangun definisi secara definitif konsep tersebut. Sebaliknya, Singleton menawarkan definisi stipulatif berupa konsep kompleks dalam hal apa artinya spiritualitas dalam suatu konteks atau pembahasan tertentu. Beranjak dari fenomena-fenomena yang terjadi itulah betapa pentingnya menumbuhkan sikap spiritual dan sosial dalam diri siswa. Oleh sebab itu pemerintah menganggap pengembangan kurikulum merupakan langkah strategis untuk menyelesaikan persoalan yang sedang dihadapi dalam dunia pendidikan kita.

Pemberlakuan kurikulum 2013 yang berorientasi pada pembentukan karakter diharapkan mampu membawa perubahan pada pembentukan generasi penerus bangsa yang bermartabat dan berkarakter. Kurikulum 2013 dikembangkan sedemikian rupa sehingga setiap pendidik diharapkan mampu mengintegrasikan kompetensi sikap spiritual dan sosial dalam setiap pembelajaran. Kurikulum 2013 membagi kompetensi sikap menjadi duayaitu kompetensi sikap spiritual yang berkaitan dengan pembentukan peserta didik yang beriman dan bertaqwa dan sikap sosial yang terkait dengan pembentukan peserta didik berakhlak mulia, mandiri, demokratis, dan bertanggung jawab. Menurur Neurosains adalah ilmu yang mempelajari tentang sel saraf atau neuron.

Perkembangan neurosains telah menyentuh dimensi spiritual. Terdapat empat hal yang bila digabungkan akan menghasilkan spiritualitas yaitu makna hidup, emosi positif, pengalaman spiritual, dan ritual. Melalui jasa SPECT, Daniel Amen membagi otak dalam lima sistem utama yaitu: korteks prefrontalis, sistem limbik dalam, ganglia basalis, girus singulatus, dan lobus temporalis. Kelima sistem ini memiliki hubungan dengan spiritualitas. Alat yang dapat mengukur spiritualitas serta menggambarkan hubungannya dengan otak, antara lain ialah Indonesian Spiritual Health Assessment (ISHA).

\footnotetext{
${ }^{6}$ Singleton et al (2004: 250)
} 
Penelitian ini bertujuan untuk mengetahui hubungan kinerja otak dan spiritualitas pada pemimpin agama di kota Tomohon. Penelitian ini bersifat deskriptif dengan metode survei analitik. Sampel penelitian ialah pendetapendeta GMIM dengan jumlah 51 orang. Data penelitian dianalisis menggunakan uji korelasi Spearman. Nilai rata-rata otak khususnya sistem limbik yaitu 5,80 (baik), sedangkan spiritualitas khususnya ritual yaitu 155,50 (sangat baik). Hasil uji korelasi Spearman menunjukkan nilai $\mathrm{P}=0,013$ yang berarti hubungan kedua variabel bermakna. Kesimpulannya terdapat hubungan bermakna antara kinerja otak dan spiritualitas manusia diukur dengan menggunakan ISHA pada pemimpin agama di kota Tomohon.

\section{Pembahasan}

\section{A. Sikuit Spiritual}

Menurut Taufiq Pasiak dalam Revolusi, 2016 terdapat empat bukti penelitian yang memperkuat dugaan adanya potensi spiritual dalam otak, yaitu potensi untuk membentuk kesadaran sejati manusia tanpa pengaruh pancaindra dan dunia luar. Keempat bukti tersebut adalah 1) Osilasi $40 \mathrm{~Hz}$ yang ditemukan Denis Pare dan Rudolpho. Dengan alat MEG ( Magnetoencephalography ) ditemukan bahwa gerakan-gerakan saraf akan berlangsung secara terpadu pada tingkatan frekuensi $40 \mathrm{~Hz}$; 2) Alam bawah sadar kognitif yang ditemukan oleh Joseph Ledoux 3) God Spot pada daerah temporal yang ditemukan oleh Ramachandran; 4) Somatic Marker yang ditemukan oleh Antonio Damasio. Secara neurologis, Tuhan telah meninggalkan "jejak-Nya" dalam diri manusia. Adanya noktah Tuhan membuat manusia sanggup berpikir dalam kerangka nilai (value).

Pelembagaan tersebut secara umum disebut agama dan merupakan sistematisasi dari fungsi spiritual otak. Ketika seseorang menganut suatu agama, itu berarti ia sedang mewujudkan dimensi spiritual atas otaknya. Ketika seseorang tidak menganut agama secara formal tetapi mewujudkan nilai dalam perilaku hidupnya berarti ia sedang mewujudkan dimensi spiritual dalam otaknya. Optimalisasi otak spiritual akan membuat seseorang hidup lebih baikdan bermakna, apapun agamanya. Otak spiritual, tempat terjadinya kontak manusia dengan Tuhan melalui alam pikiran hanya akan berperan jika otak rasional dan pancaindra telah difungsikan secara optimal. Cara kerja otak spiritual disebut berpikir intuitif. 
Hasil kerja dari kerja intuitif disebut kecerdasan spiritual (SQ). Pada dasarnya SQ merupakan kecerdasan untuk menghadapi dan memecahkan persoalan, khususnya terkait dengan makna hidupdan nilai. SQ yang kuat akan menjadi landasan kokoh untuk memfungsikan IQ dan EQ secara efektif. SQ digunakan untuk bergulat dengan ihwal baik dan buruk, serta untuk membayangkan kemungkinan yang belum terwujud. Sebagai salah satu untuk mengoptimalkan otak spiritual (berpikir intuitif) adalah dengan melihat suatu masalah secara utuh, mengkaji dari yang tersirat dan merenungkannya secara mendalam. Di setiap agama manapun berdoa merupakan cara paling efektif untuk mengoptimalkan otak spiritual. Area prefrontal otak berperan penting sebagai "alarm" tanda bahaya. Semua daerah diotak mempunyai hubungan dengan area prefrontal, baik melalui saraf maupun neurotransmiter. Area prefrontal juga memiliki mekanisme unik untuk mempertahankan kehidupan sadar manusia/ koneksi saraf secara kimiawi memungkinkan area prefrontal berperan dakam dua keadaan, baik sadar maupun tidak sadar. Pada kedaan bawah sadar, pengaturan firasafat atau intuisi terjadi. Inilah sumber "alarm" dan sekaligus sumber pemecahan bagi kasus-kasus yang tak dapat diselesaikan secara rasional.

\section{B. Ritual / Do'a dan Sistem Saraf Otonom}

Menurut Jendy Cliff dalam Hunungan Kinerja Otak, bahwa spiritualitas merupakan keyakinan yang berkaitan dengan Yang Maha Kuasa dan Maha Pencipta. Spiritualitas merupakan bagian penting dari kesehatan karena diduga dapat berperan sebagai penyembuh dari segala macam penyakit. Penelitian Kinarsih dan Wahyuningsih menunjukkan bahwa pasien lansia di RS Baptis Kediri dengan pendampingan spiritual memiliki motivasi kesembuhan yang sangat tinggi, sehingga mendukung asuhan keperawatan yang diberikan Sifat dan perilaku spiritual, pengalaman spiritual, emosi positif, dan ritual memiliki pengaruh yang luar biasa dalam banyak hal, khususnya di bidang kesehatan.

Hasil riset menunjukkan bahwa individu yang hidup dengan komponen-komponen spiritual memiliki kehidupan yang relatif sehat dan lebih bahagia. Sampai saat ini dimensi spiritual masih kurang diperhatikan dalam dunia kesehatan. Sebagai contoh, dalam pemeriksaan kesehatan baik untuk kepentingan pemetaan ataupun untuk tes kelayakan, dimensi spiritualitas sering diabaikan.meneliti pasien kanker serviks di Afrika dan mendapatkan bahwa banyak pasien mengaitkan kesembuhannya dengan spiritual yang dimilikinya. 
Pasien tersebut mengakui adanya kesulitan hidup dalam keadaan sakit, namun spiritualitas memungkinkannya untuk mengatasi kesulitan tersebut.

Sifat dan perilaku spiritual, pengalaman spiritual, emosi positif, dan ritual memiliki pengaruh yang luar biasa dalam banyak hal, khususnya di bidang kesehatan. Hasil riset menunjukkan bahwa individu yang hidup dengan komponen-komponen spiritual memiliki kehidupan yang relatif sehat dan lebih bahagia. Sampai saat ini dimensi spiritual masih kurang diperhatikan dalam dunia kesehatan. Sebagai contoh, dalam pemeriksaan kesehatan baik untuk kepentingan pemetaan ataupun untuk tes kelayakan, dimensi spiritualitas sering diabaikan.meneliti pasien kanker serviks di Afrika dan mendapatkan bahwa banyak pasien mengaitkan kesembuhannya dengan spiritual yang dimilikinya. Pasien tersebut mengakui adanya kesulitan hidup dalam keadaan sakit, namun spiritualitas memungkinkannya untukmengatasi kesulitan tersebut.Kegiatan spiritual dalam otak manusia merupakan hasil kerja dari sejumlah komponen otak yang dinamakan operator kognitif. Komponen otak ini bekerja untuk menghasilkan pengalaman spiritual.

Operator kognitif terdiri dari korteks prefrontalis, area asosiasi, sistem limbik, dan sistem saraf otonom. Berbagai penelitian menunjukkan fungsi spiritual bersumber dari dalam otak.Penelitian-penelitian ini menghadirkan adanya pengukuran dan pemeriksaan terhadap spiritualitas serta hubungannya dengan otak, salah satunya Indonesian Spiritual Health Assessment (ISHA). Alat ukur ini dibuat berdasarkan konsep-konsep teoritis spiritualitas. ISHA berbentuk kuesioner dan terdiri dari tiga komponen yaitu spiritual health item, brain system assessment, dan neurofeedback Pemimpin agama atau pemimpin spiritual merupakan orang-orang yang memimpin kegiatan agama tertentu. Pemimpin agama dan pengikutnya mempelajari halhal spiritual.

Dengan aktifitas yang selalu berkaitan dengan spiritual, pemimpin agama diyakini memiliki spiritualitas yang tinggi. Sampai saat ini, di Sulawesi Utara khususnya di Tomohon belum pernah dilaporkan penelitian tentang hubungan otak dan spiritualitas. Dengan adanya penelitian seperti ini, dapat dinilai baik buruknya kinerja otak dan spiritualitas seseorang khususnya para pemimpin agama yang menjadi panutan dalam kehidupan beragama. Saat ini banyak pemimpin agama yang mulai diragukan spiritualitasnya. Kasus-kasus yang melibatkan para pemimpin agama menunjukkan kemungkinan adanya ketidaklarasan hubungan antara kerja otak dengan spiritualitas pemimpin agama tersebut. 
Menurut Kinarsih (dalam Dampak Doa kegiatan ritual motorik seperti menari, atau menyanyi dalam sebuah seremoni tertentu memberikan pengaruh signifikan pada pusat emosi di sistem limbik. Akibat keterlibatan pusat emosi dan sistem saraf otonom, pelaku ritual dapat mengalami keadaan yang menyenangkan dan menggembirakan. Berbagai riset menunjukkan mereka yang mempraktikan perilaku ritual tertentu seperti pelayanan keagamaan, meditasi, dan kegiatan fisik tertentu memiliki fungsi fisiologi tubuh yang baik serta perubahan sistem kekebalan tubuh yang positif. Fungsi-fungsi ini diatur oleh hipotalamus,yang juga merupakan bagian dari sistem limbik.Salah satu bentuk ritual yang sering dilakukan ialah doa.

Dari perspektif neurobiologi, doa yang dipanjatkan memberikan efek berupa pengalaman emosi, dan transendensi yang dalam dan kuat. Isi doa memberi efek langsung terhadap pusat emosi otak yaitu sistem limbik.Herbet Benson, seorang ilmuwan dari Harvard University, melakukan penelitian tentang doa untuk memahami pikiran seseorang terhadap tubuhnya. Benson mendokumentasikan MRI brain scan yang menunjukkan perubahanfisik yang terjadi pada tubuh seseorang pada saat berdoa. Hasil MRI memperlihatkan gambaran aktivitas otak yang kompleks dimana sistem limbik menjadi lebih santai serta aktivitas fisiologis menjadi lebih merata.

\section{Makna Hidup}

\section{Kebermaknaan Hidup}

Manusia dan keinginan untuk hidup bermakna merupakan satu kesatuan yang tidak dapat dipisahkan. Makna hidup adalah sesuatu yang oleh seseorang dirasakan penting, berharga dan diyakini sebagai sesuatu yang benar serta dapat menjadi tujuan hidupnya. Makna hidup dapat berupa cita-cita untuk kelak menjadi orang yang sukes dan adanya keinginan untuk membuat seseorang dapat bertahan hidup. Kebermaknaan hidup akan dimiliki seseorang jika dia dapat mengetahui apa makna dan tujuan hidupnya.

Tidaklah cukup manusia menjalani hidup dengan pijakan argumenargumen yang bersifat rasional dan emosional. Bahkan tidaklah cukup bagi orang untuk menemukan kebahagiaan dengan kerangka menurut mereka sendiri. Mereka ingin mempertanyakan kerangka itu sendiri, nilai-nilai kehidupan dan berusaha menemukan nilai-nilai yang baru yang lebih sulit ditangkap dan hanya dapat diperoleh melalui kecerdasan spiritual yang ada masing-masing individu. 
Kondisi inilah yang memicu munculnya pertanyaan, pentingkah peran kecerdasan spiritual dalam suatu proses pencarian makna hidup? mengapa kita memerlukan kecerdasan spiritual?, dan mengapa kita memerlukan SQ dalam mencapai kebermaknaan hidup?serta mengapa makna merupakan kebutuhan yang mendasar saat ini? ${ }^{7}$

Memiliki kehidupan yang bermakna merupakan dambaan semua manusia. Kehidupan yang bermakna tidak dapat digantikan oleh apapun. Menurut Bastaman, keinginan manusia untuk hidup bermakna memang benarbenar merupakan motivasi utama pada manusia. Hasrat inilah yang mendasari kegiatan manusia, misalnya bekerja dan berkarya agar kehidupannya dirasakan berarti dan berharga.

Pemenuhan dari hasrat untuk hidup bermakna ini akan menimbulkan perasaan bahagia pada diri individu. Sebaliknya bila hasrat ini tak terpenuhi akan mengakibatkan terjadinya kekecewaan hidup dan penghayatan diri hampa yang bila dibiarkan berlarut-larut akan menimbulkan berbagai gangguan perasaan dan penyesuaian diri yang menghambat pengembangan pribadi dan harga diri. Motivasi yang sangat kuat dalam diri manusia untuk mampu memperoleh hidup yang bermakna berlaku pada seluruh manusia tanpa mengenal lapisan budaya maupun aspek-aspek kemanusiaan yang lain.

Mutlaknya kebutuhan akan makna hidup ini ditunjukkan oleh beberapa penelitian tentang kebutuhan individu akan makna hidupnya. Suatu hasil pengumpulan pendapat umum di Prancis, misalnya, menunjukkan 89\% responden percaya bahwa manusia membutuhkan "sesuatu" demi hidupnya, sedangkan $61 \%$ di antaranya merasa bahwa ada sesuatu yang untuknya mereka rela mati. Dari penelitian diatas mampu menggambarkan bahwa eksistensi kebermaknaan hidup menjadi kebutuhan yang mutlak khususnya pada masyarakat yang telah mengalami kompleksitas permasalahan hidup yang berindikasi adanya stressor yang kerap berdampak pada ketidak stabilan emosi, melemahnya kepercayaan diri, hilangnya motivasi untuk berkarya, merosotnya nilai-nilai kehidupan dan dorongan untuk berperilaku amoral yang mengarah pada psikososial.* Makna hidup sebagai suatu kebutuhan psikologis yang eksistensinya mutlak diperlukan bagi semua lapisan individu untuk

\footnotetext{
${ }^{7}$ Hamid AY. Bunga Rampai Asuhan Keperawatan. Jakarta: Penerbit Buku Kedokteran EGC, 2008. 18-19
} 
menopang dirinya agar mampu memperoleh kepuasan batiniah sehinnga upaya untuk menjalani kehidupan berlangsung secara sehat.

\section{Sumber-Sumber Kebermaknaan Hidup}

Frankl (dalam Bastaman, mengatakan bahwa ada tiga factor yang berpengaruh pada diri manusia sehinnga ia dengan mudah dapat mencapai tingkat kehidupan yang bermakna; Creative values (nilai-nilai kreatif): bekerja dan berkarya serta melaksanakan tugas dengan keterlibatan dan tanggung jawab pada pekerjaan. Dalam realisasinya, manusia menjalani dinamika hidupnya dengan bekerja adalah untuk menjadi sarana baginya dalam menemukan dan mengembangkan makna hidup. Menurut Frankl dengan teori Logoterapi makna hidup adalah hal-hal yang oleh seseorang dipandang penting, dirasakan berharga dan diyakini sebagai sesuatu yang benar serta dapat dijadikan tujuan hidupnya. Setiap individu normal senantiasa menginginkan dirinya menjadi orang yang berguna dan berharga bagi keluarganya, lingkungannya serta bagi dirinya sendiri. Keinginan ini merupakan motivasi utama bagi setiap manusia.

Hasrat inilah yang mendasari manusia dalam beraktifitas misalnya bekerja, berkarya, agar hidupnya dirasa berarti dan berharga. Hasrat ini yang menjadikan diri kita menjadi pribadi yang bermartabat, terhormat dan berharga (being somebody) dengan kegiatan yang mengarah pada tujuan hidup yang jelas dan bermakna. Terpenuhinya hasrat untuk hidup bermakna akan menimbulkan perasaan bahagia, dan sebaliknya kegagalan dalam pemenuhan untuk hidup bermakna akan berdampak pada kekecewaan hidup dan penghayatan diri hampa tak bermakna yang bila dibiarkan berlarut-larut akan berdampak pada gangguan penyesuaian diri, hambatan pengembangan pribadi dan harga diri ${ }^{8}$.

Dengan mengembangkan konsep yang dimiliki Frankl, Crumbaugh dan Maholick menjelaskan bahwa karakteristik individu dengan pencapaian makna hidup dapat dilihat dari cirri-cirinya yakni : (a) memiliki tujuan yang jelas, yaitu segala sesuatu yang dilakukan memiliki kejelasan akan tujuan hidup, (b) kepuasan hidup, dimana sejauhmana seseorang dapat menikmati

\footnotetext{
${ }^{8}$ Bastaman, Hana Djumhana, Integrasi Psikologi Dengan Islam; Menuju Psikologi Islam, Yogyakarta: Pustaka Pelajar.1995: 194
} 
dan merasa puas menjalani aktivitas, (c) kebebasan berkehendak, yakni mampu mengendalikan kebebasan hidup yang dilakukan secara bertanggungjawab, (d) Kontrol diri, dimana dalam keadaan apapun manusia masih bisa melestarikan kebebasan spiritual dan kebebasan berfikir, (e) sikap terhadap kematian, yaitu bagaimana seseorang berpandangan dan kesiapannya menghadapi kematian, (f) mampu memiliki alasan untuk tetap eksis. Hal ini sebagaimana yang dikatakan oleh Nietzsche "he who has a way to live fo can bear with almost any how",

Urgensi untuk hidup bermakna menjadi salah satu motivator bagi individu dalam berperilaku. Seseorang yang hidupnya hampa cenderung mudah putus asa, dan sebaliknya seseorang yang hidupnya bermakna maka mereka akan cenderung optimis dan pantang menyerah sebagaiman Mubarok mengatakannya. Untuk itulah maka banyak pengalaman yang bersifat personal sering merubah sifat dan perilaku individu ke arah lebih baik sebagai upayanya untuk mencapai hidup yang bermakna.

\section{Logoterapi Dan Makna Hidup Perspektif Islam}

Ketiga nilai yang dikenalkan oleh Frankl tidak jauh berbeda dengan konsep Islam dalam membangun kebermaknaan hidup bagi umatnya. Islam memandang bahwa segala kehidupan yang dilakukan oleh manusia merupakan rangkaian ibadah sebagaimana tujuan diciptakannya kehidupan itu sendiri. Allah dalam firman-Nya telah menjelaskan bahwa: "Tidaklah Aku menciptakan jin dan manusia melainkan untuk beribadah kepada-Ku" (Qs. Adz-Dzaariyaat: 56). Eksistensi penciptaan manusia dan alam merupakan kehendak untuk menguji kesetiaan manusia dalam mengabdi kepada-Nya.

Dalam serangkaian perjalanan hidup yang bernafaskan ibadah, Allah mengatur sedemikian rupa segala dinamika kehidupan yang harus dilalui manusia. Ibadah sebagai tujuan dari kehidupan itu diciptakan disertai dengan seperangkat aturan hidup mengenai bagaimana manusia harus mengemban tugasnya dalam melakukan perjalanan ibadah mereka. Dalam perjalanan ibadah yang panjang tersebut, menunjuk semua manusia untuk menjadi khalifah di muka bumi sebagai konsekwensi keberadaan mereka ditengah keragaman makhluk ciptaan Allah. Maka sebagai khalifah, dalam perannya manusia dibebani tanggung jawab dalam memikul tugas kekhalifahan tersebut.

${ }^{9}$ Frankl, Man Search For Meaning; Mencari Makna Hidup, Hakekat Kehidupan, Makna Cinta, Makna Penderitaan, Bandung: Penerbit Nuansa, 2004: 85 
Pertanggung jawaban atas kekhalifahan terhadap dirinya, terhadap makhluk Allah disekitarnya maupun terhadap kehidupan dimuka bumi. Sebagaimana firman Allah, "Hai Daud, sesungguhnya Kami menjadikan kamu khalifah (penguasa) di muka bumi, maka berilah keputusan (perkara) di antara manusia dengan adil dan janganlah kamu mengikuti hawa nafsu, karena ia akan menyesatkan kamu dari jalan Allah. Sesungguhnya orang-orang yang sesat dari jalan Allah akan mendapat azab yang berat, karena mereka melupakan hari perhitungan (Qs. Shaad: 26).

Keyakinan bahwa hidup adalah persinggahan bagi manusia sebagai khalifah dan kelak akan diminta pertanggung jawaban akan kekhalifahannya inilah yang mendorong manusia untuk mengisi hidupnya dengan segala hal yang memberi makna baik pada dirinyamaupun pada kehidupan di sekitarnya. Dalam perspektif Islam, tiga nilai sebagai sumber makna hidup dalam Logoterapi pada dasarnya telah tersirat dalam nilai-nilai yang terdapat dalam ajaran Islam. Pada nilai kreatifitas (creative value), Allah lewat RasulNya mengajarkan manusia untuk mengembangkan nilai-nilai kreatif dalam hidupnya. Dengan berbekal akal, manusia diperintahkan untuk bekerja, berkarya dan mengasah keahliannya. Sebagaimana dalam hadits Rosul yang telah diriwayatkan oleh Baihaqi: "Dari 'Ashim Ibn 'Ubaidillah dari Salim dari ayahnya, Ia berkata bahwa Rasulullah Saw. Bersabda: "Sesungguhnya Allah menyukai orang mukmin yang berkarya" (HR. Baihaqi).

Dengan mengembangkan nilai kreatif, maka manusia dapat memberi manfaat bagi kehidupan disekitarnya. Kebermanfaatan manusia untuk orang lain telah diajarkan dalam hadits Rasul "Sebaikbaik manusia adalah yang bermanfaat bagi manusia yang laini. Maka jelaslah ketika manusia mampu mengembangkan nilai-nilai kreatif dalam hidupnya, maka ia akan memberi mafaat bagi kehidupan dirinya dan sekitarnya. Disanalah letak dari pencapaian kebermaknaan hidup mereka. Selain nilai kreatif, Islam juga mengajarkan nilai penghayatan sebagai pembentuk kebermaknaan hidup. Nilai penghayatan dapat dilakukan dengan memahami bahwa semua kehidupan mengandung kebenaran, keindahan, kebaikan dan cinta kasih. Penerimaan lingkungan terhadap hasil karya manusia sebagai wujud kreatifitas dan eksistensinya terhadap lingkungan sehinggga ia menjadi bermanfaat bagi manusia lainnya akan membantu individu untuk merasakan penerimaan eksistensinya dari lingkungan bahwa ia dicintai, diterima dan berharga. 
Penghayatan inilah yang akan membantu tercapainya kebermaknaan hidup bagi mereka. Adapun nilai terakhir adalah nilai bersikap. Islam mengajarkan manusia untuk selalu berprasangka baik dalam mensikapi semua keadaan hidupnya baik menyenangkan maupun meyedihkan. Dalam Islam mengajarkan manusia untuk mencari hikmah dalam setiap peristiwa hidup yang menimpanya. Dengan menyadari bahwa setiap kejadian meyimpan hikmah bagi penderitanya, maka perasaan gagal, putus asa dan sikap negative lainnya akan dapat dihindari. Sebaliknya akan muncul rasa tenang, optimis, ikhlas dan syukur bahwa semua menjadi karunia Allah yang terbaik yang harus dijalani.

Keyakinan bahwa semua yang menimpa adalah kehendak Allah akan menguatkan diri individu akan keyakinannya bahwa setiap ujian yang menimpa merupakan ujian dan wujud cinta Allah pada dirinya sebagaimana yang diajarkan Rosulullah dalam sebuah hadits riwayat Tirmidzi "Sesungguhnya besarnya pahala tergantung besarnya ujian. Jika Allah mencintai suatu kaum, maka Dia akan menguji mereka. Barangsiapa yang ridho, maka mereka akan mendapatkan keridhoan Allah. Dan siapa yang murka, maka akan mendapatkan murka Allah". Maka bagi sebagian individu yang memiliki sikap positif dalam setiap penderitaan (suffering) yang menimpa hidupnya akan berimbas pada kekuatan pencapaian makna hidup dalam dirinya. Dalam memandang ketiga nilai sebagai sumber makna hidup tersebut, Islam memiliki pandangan lebih komprehensif sebagai upaya pemenuhan kebutuhan spiritual manusia.

Dalam setiap fase kehidupan yang dilewati individu, implementasi ketiga nilai tersebut didasari oleh kebutuhan mendasar dari diri manusia yakni ibadah. Ketika manusia melewati semua fase hidup mereka dengan mengimplementasikan ketiga nilai tersebut, akan lebih bermakna jika semua didasari oleh niat untuk beribadah karena Allah. Semua didasari oleh kebutuhan pengabdian terhadap Tuhan serta bentuk pelaksanaan tugas kekhalifahan mereka yang akan diminta pertanggung jawabannya di hari akhir kelak. Muatan ibadah inilah yang menjadi motivator terbesar bagi diri manusia dalam mewujudkan hidup untuk lebih bermakna. 


\section{Penutup}

Banyak teori dalam psikologi pendidikan yang mencoba menjelaskan, mengarahkan dan memprediksi berbagai hal yang berkaitan dengan potensi diri pada manusia termasuk kesuksesan belajar. Penelitian tentang spiritualitas yang dikaitkan dengan kesuksesan belajar telah banyak dilakukan. Demikian ini di karenakan spiritual adalah perasaan, pikiran, pengalaman, dan perilaku yang muncul dari pencarian yang suci yang menjadi pemicu individuindividu dengan spiritualitas yang tinggi lebih efektif dan gigih dalam menghadapi kesulitan-kesulitan dan kegagalan dan lebih mungkin untuk mencapai hasil belajar yang lebih sukses.

Hasil penelitian ini menunjukkan bahwa dampak kesalahan pengambilan sampel sebesar $15 \%$, persentase yang kecil ini menunjukkan kemungkinan bias kesalahan karena kekeliruan dalam pengambilan sampel adalah kecil. Sementara hasil interval kepercayaan (rr) sebesar 333.0\%, dan hasilnya lebih besar daripada dampak kesalahan pengambilan sampel, maka dapat menunjukkan pula bahwa kemungkinan bias kesalahan karena kekeliruan dalam pengukuran adalah lebih besar. Berdasarkan hasil penelitian ini telah membuktikan bahwa ada pengaruh spiritualitas terhadap kesuksesan belajar. Hasil penelitian meta-analisis ini sebagaimana hasil penelitian meta analisis lainnya mempunyai beberapa keterbatasan. Pertama, penemuan metaanalisis adalah korelasi secara alami dan, oleh karena itu, tidak bisa menjamin kesimpulan-kesimpulan yang kuat.

Kedua, keseluruhan penemuan dari meta analisis sering dibatasi oleh mutu studi-studi utama. Ketiga, pengaruh budaya, termasuk berbagai latar belakang etnis terabaikan. Khusus ketika melakukan penelitian di Indonesia karena kebanyakan bahkan semua hasil penelitian yang digunakan dalam studi ini berasal dari luar negeri (luar Indonesia), dan mungkin masih banyak pertimbangan bila disesuaikan dengan kondisi di Indonesia.

Penelitian masa depan diharapkan dapat meliputi kriteriakriteria yang lebih ketat untuk memastikan bahwa beberapa faktor lain bisa dimasukkan seperti dengan melihat spesifikasi alat ukur spiritualitas yang digunakan, gender, budaya atau M. Nur Ghufron370 Edukasia: Jurnal Penelitian Pendidikan Islamdiperluas kriterianya guna menguji pengaruhnya terhadap alat ukur kesuksesan akademik yang spesifik pula. Demikian ini, hasil penelitian 
ini dapat menjadi petunjuk yang lebih spesifik bagi penelitian selanjutnya. Bahwa spiritualitas mempunyai pengaruh terhadap kesuksesan akademik. Untuk penelitian lainnya diharapkan mampu bersikap lebih kritis dalam memandang suatu hasil penelitian. Suatu hasil penelitian tidak dapat dipercaya secara penuh mengingat adanya artefak atau kesalahan yang dilakukan peneliti. Dari hasil penelitian ini disimpulkan terdapatnya hubungan bermakna antara kinerja otak dan spiritualitas, dalam hal ini otak dan ritual, yang diukur dengan menggunakan ISHA pada pemimpin agama di kota Tomohon. Hal ini menunjukkan bahwa pemimpin agama di kota Tomohon aktif dalam mengikuti kegiatan-kegiatan ritual dan mempunyai fungsi sistem otak yang bekerja baik. 


\section{Bibliografi}

Bastaman, Hana Djumhana(1995), Integrasi Psikologi Dengan Islam; Menuju Psikologi Islam, Yogyakarta: Pustaka Pelajar.

Fatma Laili( 2013). Peran Kecerdasan Spiritual Dalam Pencapaian Kebermaknaan Hidup KONSELING RELIGI: Jurnal Bimbingan Konseling Islam Vol. 4, No. 1, Juni. Kudus

Frankl (2004), Man Search For Meaning; Mencari Makna Hidup, Hakekat Kehidupan, Makna Cinta, Makna Penderitaan, Bandung: Penerbit Nuansa

Goleman, Daniel.(2000). WorkingWith Emotional Intelligence. (Terjemahan Alex Tri kantjono W.). Jakarta: PT Gramedia Pustaka Utama.

Hetika,Sunandar,Bahri Kamal,Analisis Pengaruh Kecerdasan Intelektual Dan Kecerdasan Emosional Terbadap Ipk Mahasiswa Prodi Akuntansi Politeknik. Harapan Bersama Tegal Dengan Kecerdasan Spiritual Sebagai Variabel Moderating, Tegal

Hamid AY. Bunga Rampai Asuban Keperawatan. Jakarta: Penerbit Buku Kedokteran EGC, 2008.

Imai Indra(2012). Aktivitas Otonom. Jurnal Kedokteran Syiah Kuala Volume 12 No 3. Aceh

Kinarsih S. Dampak berdoa bagi kesehatan [cited 2012 Des 27]. Available from: http://www.mindhealingtherapy.blogspot.com/2010/11/berdoa-dandampakpositipyang.html.com.

Mikail B. Spiritualitas dan efeknya terbadap penyembuban [cited 2012 Oct Available from

http://www.health.kompas.com/read/2012/01/16/10441523/Spirituali tas.dan.Efeknya.Terhadap.Penyembuhan.com.

Pasiak T. Assesment Spritualitas Otak.Launching CNET. Disampaikan di Aula UIN Kalijaga Jogja, 26 Januari 2012.

- Neurosains, Spiritualitas dan Psikoterapi. POKDI Psikoterapi PP PDSKJI. Disampaikan pada Konas Psikoterapi. Jakarta, Mei 2012. , Manajemen Kecerdasan: Memberdayakan IQ/EQ/SQ untuk Kesuksesan Hidup. Bandung: Mizan, 2006. 
140 | BELAJEA : Jurnal Pendidikan Islam, Vol. 3, No. 02, 2018

- Neuron to Nation. Dewan Riset Nasional-BPPT. Disampaikan di Jakarta, Agustus 2012.

- Gangguan Bipolar dan Pendekatan Neurosains Spiritual. PDSKJI Cabang Surabaya. Surabaya, 2012.

Suyadi. 2017.Teori Pembelajaran Anak Usia Dini Dalam Kajian Neurosains. Bandung: PT Remaja Rosdakarya.

Wattimena R. Memperkenalkan status neurosains [cited 2012 Oct 15]. Available from: http://www.wima.ac.id/index.php?r=university/article\&id=1057.

Wattimena R. Memperkenalkan status neurosains [cited 2012 Oct 15]. Available from: http://www.wima.ac.id/index.php?r=university/article\&id=1057. 